\title{
The Semiosis of Prayer and the Creation of Plausible Fictional Worlds
}

There is a golden rule that cryptanalysts and code breakers rely on - namely, that every secret message can be deciphered, provided that it is a message.

Umberto Eco, Six Walks in Fictional Woods

I praise you. I call your name that is hidden within me: aô eeô êêêôôô iii ôôôo oooooôôô ôô uuuuuuôô ôôôô ôôôô̂ô ôô ôôôôôôô ôô

Nag Hammadi codex VI. 6.

\section{Introducing a liminal and metaphorical landscape with forking paths}

Prayers and incantations are one of the most common subforms of religious discourse for the creation, actualization and maintenance of plausible fictional worlds. In this article I will venture the thesis that the semiosis of prayer, having as I see it a liminal position and a transitional function, facilitates the creation not only of possible fictional worlds, but also of highly plausible ones, that is 'plausible' for the religionists. Prayers and incantations are subsequently liminal and transitional 'mechanisms' that may accomplish that a possible world is credited to be a most plausible one by an interpretive community of religionists.

The first community or group to be dealt with is made up of those consulting a ritual specialist in 'holy magic', as described in the Greek Magical Papyri (= PGM 1/127). The other interpretive community consists in those who heard the Hermetic tractates being read aloud in, we may presume; 'small, informal circles of the literate but not (usually) learned gathered round a holy teacher and given up to study, asceticism and pious fellowship' (Fowden 1993: 193).

Prayers and incantations are for both of these groups mechanisms of transition - well-trodden paths of communication - which not 
only bridge the space between the literal and the oral, between transformative words and performed rituals, ${ }^{1}$ but they even transcend human language and ordinary human communication, culminating in sounds and iconographical signs from the Unlimited; voces magicae, 'magical graffiti' or god-speaking silence. The gods' answers, the messages to the person praying or incantating, are in these cases signs with unlimited sense; open symbols ${ }^{2}$ over-coded by their co-text to be expressions of an unlimited divine significance. However, the signifiers are often nonsensical for outsiders, but used by a religious interpretive community, nonsensical signifiers are deemed both to be iconic signs (in Pierce's terminology), and vehicles of unlimited signification and meaning. They are semiotic mechanisms, that through their inability to be fully decoded in a given human language, ${ }^{3}$ creates the expectation - for the religioniststhat these signifiers belong to the Unlimited, and that they therefore are signs bridging the liminal landscape set between the actual empirical world and what I have called the Unlimited.

In PGM 1/216-221 we have the invocation (E. N. O'Neil's transl. in Betz 1996: 8):

Aye, lord, because I call upon your secret name which reaches from the firmament to the earth, ATHEZOPHOIM ZADEAGEOBEPHIATHEAA AMBRAMI ABRAAM THALCHILTHOE ELKOTHOOEE ACHTHONON SA ISAK CHOEIOURTHASIO IOSIA ICHEMEOOOO AOAEI, rescue me in an hour of need.

A god's secret name, a message coming from the heavenly or stellar firmament and reaching earth, is to be used as an invocation that guaranties the communication between the empirical and the $\mathrm{Un}$ limited. ${ }^{4}$ Parts of the voces magicae can be decoded and related to a

\footnotetext{
${ }^{1}$ We may discern between prayer or incantation as a linear text manifestation, as an act or we may choose to analyze the subject/the content of it. See Gill 1987: 489.

2 'Symbol' is here indicating a sign partaking of the signified, having therefore a non-arbitrary relation to it. Symbol in this sense is the iconic sign in Peirce's terminology.

${ }^{3}$ In a voces magicae formula we may find Egyptian, Coptic, Greek, Jewish, Persian words etc, but a such a formula is not ordinarily a sentence that may be fully decoded, using the conventional syntax or semantics of these or other human languages.

${ }^{4}$ We may compare with the Greek vowels as signifying the hebdomad of astral rulers and perhaps used as a means to ascend (Keizer 1974: 41-43 and see the magical formula in the introduction of my article). But also the
} 
specific signified content, e. g. the names ABRAAM and ISAK. But its main semiotic function is being an open symbol, an expression of unlimited and ambiguous divine significance. It partakes of what it signifies and can therefore be used as a means of communication between the actual and the Unlimited.

We may here compare with how Iamblichus (De Mysteriis VII. 45) defends and explains the use of 'barbarian names' (onomata barbara) and especially 'meaningless names' (asema onomata) in a Greek-speaking religious context. The barbarian names were revealed by the gods to the Assyrians and Egyptians in primordial time and are therefore, even if they are not quite understandable, to be preferred and used, instead of Greek novelties. The meaningless names - in all probability voces magicae or other sequences of vowels - are meaningless for us humans, living our lives dependent on the senses - because their real significance, their supersensible intelligibility, is only known by the gods. In Corpus Hermeticum (XVI. 2) we can read a comparable passage that repudiates that the Hermetic knowledge should be translated into Greek where it is stated 'We (sc. the Egyptian Hermetists) do not use arguments (sc. like the Greeks), but rather utterances filled with power'. I think that we have here, in the aforementioned passages, emic statements about iconic signs, which partake of the divine that is signified. Open symbols that can be used as a means of connecting the empirical with the Unlimited. ${ }^{5}$

The open symbol's signified can furthermore be as unlimited and ambiguous as it is mentally and imaginatively conceivable, which means that the set of possible fictional worlds that it may refer to is unlimited and maximally varied (Dolezel 1989: 231). But these worlds must belong to what I have labeled the class of plausible worlds. Fictional worlds that are made plausible by a religious interpretive community.

I will accordingly postulate a theoretical model consisting in an actual or empirical world and a possible - for the religionists plausible world. The first one, the starting-point in my game whose rules you will soon recognize, is called 'The actual and empirical world' and the other-one, the goal to be gained or wellspring to be tapped by the religionists, is labeled 'The Unlimited'. But my demi-

Neoplatonic theurgy is here of interest. Hans Lewy has remarked that symbola, synthemata and voces mysticae, viz. arreta onomata, are identical, because Proclus (Tim. I. 211. 1) uses them as synonyms (1978: 192).

${ }^{5}$ The glossolalia -praxis, codified in the New Testament, also belong to this category of signs. 
urgical activities are even further complex, because betwixt and between these worlds is set a liminal landscape, designed by the 'team' van Gennep (1960) and Victor Turner (1969; 1981; 1985 a; 1985 b).

I will use this triadic model as a heuristic metaphor, whose copula is the liminal landscape. A landscape that has emic and etic paths, communicating or interpreting the divine communication; the transition from the actual and empirical to the Unlimited, and the answers from the Unlimited. A person praying or incantating performatively turns herself into a liminal persona who uses those emic paths that her culture has outlined.

Victor Turner has drawn up some characteristics of liminality as applied especially to ritual behaviour. It may be regarded as "the "subjunctive mood" of culture, the mood of may-be, might-be, as-if, hypothesis, fantasy, conjecture, desire, depending on which of the trinity, cognition, affect, and connation, (thought, feeling, or intention) is situationally dominant (Turner $1985 \mathrm{~b}: 295$ )'. I find it useful to view prayer and incantation as a major discourse of liminality. A discourse or path that delineates a possible world, but that also has built-in semiotic mechanisms that transform mere possibility into socially shared plausibility, thus building up a most plausible world for the religionists, a world that is deemed to have more ontological stability than the empirical world.

The object of study is therefore the liminal, narratological, transitional and mental mechanisms that enable a person(-s) praying or incantating to 'vivify' a narrative and fictional world, so that it is furnished with such an aura of factuality that the inhabitants of this fictive world - gods or other metaphysical creatures - may 'answer' the religionist in various ways, including voces magicae or mysticae. ${ }^{6}$ The possible and fictional world is in this case seen as a most plausible one. The bridging between these ontologically different worlds is accomplished by the actualization of a religious discourse and especially by the act of praying or incantating, since this subform of religious discourse is a prime exponent of religious semiosis.

The technical term semiosis denotes the signification process in general, and it is often used as a covering term for the process by which empirical subjects communicate, communication processes being made possible by the organization of signification systems' (Eco 1976: 316). Various religions or religious discourses are of

\footnotetext{
${ }^{6}$ This subject is going to have an in-depth analysis in my forthcoming dissertation The Discourse of Hermes Trismegistos. I here try to give a more limited analysis, using mainly Hermetic prayers as material.
} 
course paramount examples of complex signification systems; a veritable plethora of crisscrossing similarities, dissimilarities and inversions, all of them making up a Wittgensteinian family resemblance that is multi-heterogenous and which lacks a common essence. But it is nevertheless a praxis that we dare to call religion.

And if religion is, as Bruce Lincoln states, "that discourse whose defining characteristic is its desire to speak of things eternal and transcendent with an authority equally transcendent and eternal' (1996: 225), then prayers and incantations, take a central place in these signification systems, as a form of divinely-authorized human communication with postulated non-human, transcendent agents, agents that may reveal themselves for the religionists in our actual and empirical world, but who have their habitat in a plausible world that is fused to the actual.

\section{To narrate a possible world and making it plausible through prayer and incantation}

Prayers and incantations are, as I see it, narrative constructs that try to manipulate an empirical reader to become a model reader that 'identifies' with a role outlined in the narrative, and thereby also enacts the story, or comes to partake in the historiola of a magical papyrus. A model reader is therefore, if we are to follow Umberto Eco, 'a set of textual instructions' that outlines what sort of empirical reader that is anticipated, and how she (if a female person is intended) (PGM 8/1-63) should read and we may add, enact her part of the plot. The Greek magical papyri are even textual machines that are consciously encoded with an empty slot, a place for the nomen nescio, wherein one puts one's own name. If I therefore eagerly turn to 'Binding love spell of Astrapsoukos' (Preisendanz 1931: 8/163), I have already been somewhat compromised as empirical reader, but the outlines of the model reader has really begun to take shape. And, as in all effective communication, there is a lot of redundancy, and the title is not quite the whole story, because the spell is promoting commercial and other success ventures. ${ }^{7}$ It begins with a threefold petition to be said to Hermes (E. N. O'Neil's transl. in Betz 1996: 145):

\footnotetext{
${ }^{7}$ Note that the spell and the ritual instruction is aimed at 'helping' a shopkeeper, and that the title is therefore somewhat odd.
} 
Come to me, lord Hermes, as fetuses do to the wombs of women. Come to me, lord Hermes, who collect the sustenance of gods and men; [come] to me, NN, lord Hermes, and give me favour, sustenance, victory, prosperity, elegance, beauty of face, strength of all men and women. Your name in heaven: LAMPHTHEN OUOTHI OUASTEN OUOTHI OAMENOTH ENTHOMOUCH.

A very precise model reader is outlined, and a role is offered up in a ritual sequence, that may also be analyzed as a narrative plot, or a script with a role to take over and to enact. And enacting the person incantating and ritually acting implies a dual role-situation, a plot or story, ${ }^{8}$ that makes the model reader also to adopt the role of the god or metaphysical actant. An adopted role that restructures and gives a new meaning to the field of perception. The empirical world is thereafter searched for divine signs and replies emanating from this actant. To pray or to incantate is to anticipate 'answers' from the Unlimited, viz. to decode the Umwelt according to the adopted religious frame of reference.

It can be said that many etic paths are here going in the same direction: I think it is fairly obvious that Victor Turner's bush-road traversing the social drama, viz. incantation as crisis-management when 'crises arise in the daily flow of social interaction' (Turner 1985 b: 177-204) is coming to the fore. But also Umberto Eco's narratological semiotics, studying literary and fictive worlds and the cooperation of empirical and model readers, can here be made to merge with the Scandinavian tradition of social constructivist rolepsychology. A line of interpretation that started with Hjalmar Sundén $(1956 ; 1959 ; 1987)$ and that is now developing in contact with narrative psychology (see Holm and Belzen 1995).

The meeting-place is the narrative construction of reality and fiction functioning as a cultural activity for the creation, actualization and maintenance of a plausible fictional world for a given interpretive community.

Any culture has a set of possible fictional worlds. Some of these worlds are held to be fictional and false; just entertaining stories for pleasure, viz. a possible world that is paradoxically also impossible. Other discourses may paint up a possible fictional world that is deemed to be true in some way. If this possible world is held to be

\footnotetext{
${ }^{8}$ The narrative discourse is how something is narrated. The story or plot are concepts that answer the question of what - the subject and its narrative plotting in a sequence - that is told about.
} 
true, ontologically focalized and privileged by a religious interpretive community, it is a plausible fictional world. ${ }^{9}$

We have here a powerful sociological factor; the interpretive community. It focalizes and privileges a plausible, or a set of plausible, religious worlds. In the Hellenistic syncretism, and especially in the interpretive community that consulted a crisis-manager, a ritualist, using and advising about the use of the Greek magical papyri, we meet a plausible fictional world that inter alia is made plausible by its extreme inter-textuality. It reverberates with echoes from many other plausible worlds. One may come from a Jewish tradition to the 'Binding love spell of Astrapsoukos', that take most of its material from the Egyptian religious discourse, and nevertheless find a voces magicae-formula beginning with the great names 'IAO SABAOTH ADONAIE' (PGM 8/61). The well-known is woven together with the unknown and the nonsensical but unlimitedly promising.

In Umberto Eco's semiotic world our spell would be called an open text that outlines a closed project for its model reader (1979: 9-10). And I have already been talking about voces magicae as an open symbol that is typical for these texts. The open text has a maze-like structure producing a rather ambiguous and redundant message that may be of use in many social and somatic crisis-situations. The text is often 'open' for implementation in various situations and it is forward-looking, but the model reader's project is strictly described in what he or she has to incantate and ritually enact. But also the appropriate state of mind may be stated.

The empirical reader (alias the magical client), troubled and driven by crises in his social drama, is manipulated to be a model reader and actor who follows the set of textual instructions given. He takes over the model reader's role and also thereby adopts a consciously encoded god-role.

It is also narratologically interesting, in some of the Greek magical papyri, that the person incantating does not only identify with a human role in the plot, and expects answers from the adopted god role as in the Abrahamitic religions, but the human role offered to the incantator is turned into being the god himself (see also PGM 4/2289, 5/249 for other identifications with Hermes/Thoth).

\footnotetext{
${ }^{9}$ All narrative qua narrative is fictional, and nothing within a narrative is in principle sufficient to determine the fictionality or non-fictionality of the narrative's reference(-s). The ontological status of the narrative's denotata, the objects and processes in the extra-textual world that are referred to, is finally decided by an empirical reader or interpretive community.
} 
This most Egyptian feature, which gives a direct link to an Egyptian ritual and 'magical' context (Podemann Sørensen 1984: 9-11), makes the incantator 'enter the narrative by identifying himself as a god. The effect is, therefore, a collapsing of boundaries between the human situation and the mythical dimension' (Frankfurter 1995: 469-470). The mythical dimension, i. e. the plausible world, is fused to the actual through this identification.

The 'Binding love spell of Astrapsoukos' clearly shows this mechanism (E. N. O'Neil's trans. in Betz 1996: 146):

Hear me, Hermes, /.../ Preserve me always, through all eternity, from drugs and deceits, every slander and evil tongues, from every daimonic possession, from every hatred of both gods and men. Let them give me favor and victory and business and prosperity. For you are I, and I am you; your name is mine, and mine

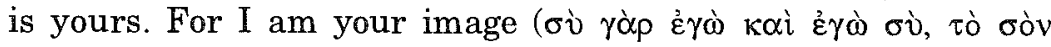

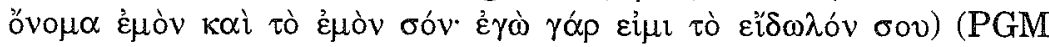
8/37-38).

In the impressive monograph Das Gebet - a mine to dig carefully so not to be crushed by apologetics - Friedrich Heiler writes 'Diese "reziproke Identitätsformel" ist das höchste mystische Gebet. Erst wenn er dieses Gebet sprechen kann, hat er seinen Gott ganz gefunden, bleibt er eins mit ihm in Ewigkeit' (1923: 306-307). Heiler has noticed the formula's presence in our philtrokatádesmos and in some other texts (Iren. I. 7. 2; Epiphan. Haeres. 26. 3), but has placed it as the crown of mysticism. Also Betz, in a most admirable article "The Delphic Maxim "Know yourself" in the Greek Magical Papyri', seems to follow this line of thought; 'Characteristic for the magical literature, it is the knowledge of the secret name that establishes the ground for the mystical union'(1990: 168). But is it possible to speak of 'mystical union' or 'the highest mystical prayer' in this context, a context that is replete with mundane longings, set in an Egyptian 'magical scene' with the knowing of voces magicae etc.?

I do not think so. It is perhaps better to respect the ritual context in the Greek magical papyri and label it a ritually enacted union, viz. a union that is thought to be accomplished through the transformative force of the incantated words. The function of this ritually enacted union in our text is interesting, because through it the plausible world is fused to the actual in the person incantating and ritually acting.

From a theoretical perspective, coming from possible worlds semantics as applied to fictional worlds, it has been noticed that: 
'Often, objects belong to two different set of worlds and have different properties, functions and ontological weight in each of these./../ Sacred being and objects, miraculous or prophetic grottos, holy mountains, places of worship, all these provide for the points of articulation at which two worlds meet in what could be called a series of ontological fusions' (Pavel 1989: 251). This may have a nostalgic ring for those of us that have wandered in Mircea Eliade's Arcadian landscape, without knowledge of the $E t$ in Arcadia ego of theoretical and explanatory perspectives.

But, I do think that Eliade's observation used by Thomas Pavel, is still to the point. There are objects belonging to two different sets of worlds if we are following the line of thought of any interpretive community promoting plausible worlds.

The focalized point of fusion, with 'objects' belonging to both worlds, is in our text the voces magicae, the manufacturing of a magical figurine and perhaps most important; the ritually enacted union.

We have already acquainted Hermes' heavenly names in the threefold petition. The foreign names are also given in the spell 'PHARNATHAR BARACHEL CHTHA' (PGM 8/21). But also his true name 'OSERGARIACH NOMAPHI' (PGM 8/45) that is said to be inscribed on a sacred stele in his birthplace, Hermopolis. And knowing a name is to partake in an identity.

The merging of identities and role-plots is also made in a very concrete way, since the god is 'inscribed' in the life-story of the magical client in the following way: It is instructed that the client should make, of olive wood, a small dog-faced baboon - a form of Anubis that is identified with Hermes, because it shall wear his attribute, a winged helmet. ${ }^{10}$ This syncretistic cult image shall on its back carry a box, and within it shall be put a papyrus inscribed with Hermes' name, here given as 'PHTHORON PHTHIONE THOYTH' (PGM $8 / 60$ ). The magical client shall pray for what he is doing while fashioning this object, and also pray for what he wishes. It is then to be placed in the middle of his workshop and thereby being concretely 'inscribed' in his every day life-story.

The ritually enacted union between the magician and the god Hermes Trismegistos: 'For you are I, and I am you; your name is mine, and mine is yours. For I am your image' is a summoning up and concentration of the fusion of the actual and Unlimited world. A fusion that is strengthened and made even more thoroughgoing

${ }^{10}$ The Greek Hermes is of course amalgamated with Hermes Trismegistos viz. Thoth. 
through the voces magicae. It is also implicated that as a consequence of the formula, having the same identity as the god, the god also shares in the human's destiny. If anything should happen to the person incantating, it could also happen to the great god, whose name is in this context given as 'ACHCHEMEN ESTROPH (PGM 8/40-41). He, the stronger, will - one may conclude - avert all threatening influences. The life story of the human and the god is made into one. The person incantating has knowledge of the god's names and is his image. The incantating person's name is the god's. It can perhaps be said that they mirror each other (see Betz 1990: 165-167). The weak and transient is strengthened through its association with the strong and unlimited.

It is a formula that has such importance and illocutionary force that it is repeated in what could be called 'magical redundancy', strengthening the message: 'I know you, Hermes, and you know me. I am you, and you are I. And so do everything for me, and may you turn to me with Good Fortune and Good Daimon, immediately, immediately; quickly, quickly' (E. N. O'Neil's trans. in Betz 1996: 146. See also Betz 1990: 164-168).

\section{The Beholder's Share, Phase Shifting and a Summing Up}

The famous art historian Sir Ernst Gombrich time and again stressed the importance and creative power of the beholder, the beholder's share, in the process of art-perception (1982: 154-244). Certain walls stained with damp, or stones of uneven colour were able to capture divine landscapes for Leonardo da Vinci. Clouds and the ink-blots of Rorschach were also filled in with 'meanings' and, as we now could say, with possible worlds. But mechanisms recognized in art perception can also be felt in religion.

The importance and power of the beholder's share is also paramount for those praying and incantating in the Greek magical papyri or being active in a small circle of Hermetists who are seeking to be deified. And the beholder's share is promoted by an interpretive community in the actual world. This actual and empirical world was and is always present, but when is art and when is religion?

My answer to the last question is: When an empirical reader, driven by social crisis or convention - manipulated by a religious discourse, and especially the semiosis of prayer and incantation perceive the world around as a model reader, one who is outlined in incantations and prayers, and in the religious discourse at large. 
And being a model reader in this kind of discourse implies that a possible world is transformed to a plausible. The plausible world may be identical with the actual in a strong fusion, in Pavel's terminology, so that every object in the actual world is decoded as also having a place in the plausible. This would equate a panentheistic world view, conjuring up a plausible world for the Hermetists as in the concluding hymn in Corpus Hermeticum V. 11 (Copenhaver 1992: 20):

When shall I sing a hymn to you? One cannot detect in you time or season. For what shall I sing the hymn - for what you have made or what you have not made, for what you have made visible or what you have kept hidden? And wherefore shall I sing the hymn to you - for being something that is part of me, or has a special property, or is something apart? For you are whatever I am; you are whatever I make; you are whatever I say. You are everything, and there is nothing else; what is not, you are as well. You are all that has come to be; you are what has not come

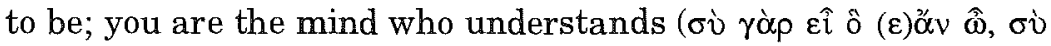

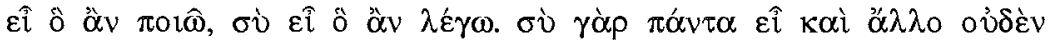

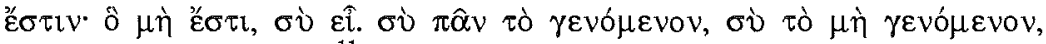
vovิ $\mu^{\prime} \varepsilon$, voov́ $\left.\mu \varepsilon v o \varsigma\right),{ }^{11}$ the father who makes his craftwork, the god who acts, and the good who makes all things.

Not only ontological and static qualities of the union between man and god are emphasized (the ousía aspect), but also processual and creative aspects (the génesis aspect); 'you are whatever I make; you are whatever I say'. A model reader is created that is designed to perceive both his acting and saying as the work of god.

We have here what Hjalmar Sundén called a phase shift. The world around, and even the person praying himself, can now be perceived as god, an eternal and omnipresent Thou who also merges with the ' $\mathrm{T}$ ', now as the actual and empirical world (1959: 111). But a necessary condition for this phase shift is the learning and retention of a religious discourse. An empirical reader has to learn and to take over, in this case, the verbally transmitted role of being a model reader. A model reader which 'reads' the whole cosmos as having a message.

Walter Burkert has remarked, when analyzing divination, that

The fundamental form of communication for humans is language; hence signs are appropriated and translated into the experience of language. The abundance of signs turn into a pleth-

\footnotetext{
${ }^{11}$ Nock and Festugière 1991: 65.
} 
ora of voices. A feeling of universal empathy may prevail, as if every being, everywhere, were telling a message - to those that who understand. Indistinct sounds tend to become speech for the charismatics. /.../ Speech presupposes speakers; signs seem to presuppose some great signator, a universal signifier who has established the meanings we are summoned to understand. Burkert 1996: 160-161.

If an empirical reader manages - driven by the social drama and trusting some interpretive community - to adopt the role of being a model reader, he or she may perceive the world as outlined by the religious discourse. Prayers and incantations are one of the most common subforms of this discourse, a subform that also has deep affinities with elementary human needs. They may be biological, psychological, social and ethical etc. In an article about the 'psychology of prayer' Thorvald Källstad lists the main motives for prayer as need, fear and thankfulness (1984: 107).

Prayer and incantation can perhaps be said to be 'mechanisms' that promise that lack will be liquidated and that there is an unlimited signator, a father, or some other metaphysical creature, standing behind and legitimizing the discourse. A way of communicating with the Unlimited that is privileged by an interpretive community that read the prayers aloud (Horst 1994: 1) and enacted the magical stage-scripts.

In sum: These highly overlapping categories function as one of the most common subforms of religious discourse for the creation, actualization and maintenance of plausible fictional worlds. They are liminal and transitional mechanisms that manipulate an empirical reader to phase-shift from an actual world to a plausible, by being inscribed in a possible and fictional world, thus creating a model reader, that perceives and acts according to the plausible world outlined by a given interpretive community, and that hears god talking in voces magicae and in god-speaking silence.

\section{References}

Betz, Hans Dieter

1990 Gesammelte Aufsätze; vol. 1: Hellenismus und Urchristentum. Tübingen: Mohr.

Betz, Hans Dieter (ed.)

1996 The Greek Magical Papyri in Translation. Including the Demotic Spells; vol. 1: Texts. London: University of Chicago Press. [1986] 


\section{Burkert, Walter}

1996 Creation of the Sacred. Tracks of Biology in Early Religions. Cambridge: Harvard University Press.

Copenhaver, Brian (transl.)

1992 Hermetica. The Greek Corpus Hermeticum and the Latin Asclepius. Transl. by. Cambridge: Cambridge University Press.

\section{Dolezel, Lubomír}

1989 Possible Worlds and Literary Fiction. In Sture Allén (ed.), Possible Worlds in the Humanities, Arts and Sciences. Proceedings of the Nobel Symposium 65; pp. 221-242 . Berlin: de Gruyter. (Research in Text Theory, 14).

\section{Eco, Umberto}

1976 A Theory of Semiotics. Bloomington: Indiana University Press.

1979 The Role of the Reader. Explorations in the Semiotics of Texts. London: Hutchinson.

\section{Fowden, Garth}

1993 The Egyptian Hermes. A Historical Approach to the Late Pagan Mind. Princeton: Princeton University Press.

\section{Frankfurter, David}

1995 Narrating Power: The Theory and Practice of the Magical Historiola in Ritual Spell. In: Marvin Meyer and Paul Mirecki (eds.), Ancient Magic and Ritual Power; pp. 457-476. Leiden: Brill. (Religions in the Graeco-Roman World. 129)

\section{Gennep, Arnold van}

1960 The Rites of Passage. London: Routledge and Kegan Paul.

\section{Gill, Sam D.}

1987 Prayer. In: Mircea Eliade (ed.), The Encyclopedia of Religions; vol. $11 ;$ pp. 489-494. New York: Macmillan.

\section{Gombrich, E. H}

1982 Art and Illusion. A Study in the Psychology of Pictorial Representation. Oxford: Phaidon.

\section{Heiler, Friedrich}

1923 Das Gebet. Eine religionsgeschichtliche und religionspsychologische Untersuchung. München: Ernst Reinhardt. [5. Aufl.]

Holm, Nils G., and J. A. Belzen (eds.)

1995 Sundén's Role Theory. An Impetus to Contemporary Psychology of Religion. Åbo: Åbo Akademi. (Religionsvetenskapliga skrifter, 27).

Horst, Pieter W. van der

1994 Silent Prayer in Antiquity. Numen 41: 1-25.

Keizer, Lewis H.

1974 The Eight Reveals the Ninth: A new Hermetic Initiation Discourse. Seaside: Academy of Arts and Humanities.

Källstad, Thorvald

1984 Bönens psykologi. Svensk Teologisk Kvartalstidskrift 60: 107-113. 


\section{Lewy, Hans}

1978 Chaldean Oracles and Theurgy. Mysticism Magic and Platonism in the Later Roman Empire. Nouvelle édition par Michel Tardieu. Paris: Etudes Augustiniennes.

\section{Lincoln, Bruce}

1996 Theses on Method. Method and Theory in the Study of Religion 8: 225-227.

Nock A. D., and A. đ. Festugière

1991 Corpus Hermeticum, t. 1. Texte établi par A. D. Nock et trad. par A. J.Festugière. Paris: Les Belles Lettres.

\section{Pavel, Thomas}

1989 Fictional Worlds and the Economy of the Imaginary. In Sture Allén (ed.), Possible Worlds in the Humanities, Arts and Sciences. Proceedings of the Nobel Symposium 65; pp. 250-259. Berlin: de

PGM Gruyter. (Research in Text Theory, 14).

1928-31Papyri Graecae Magicae: Die Griechischen Zauberpapyri; vol. 1-2. Ed. by Karl Preisendanz. Leipzig : B.G. Teubner Verlag.

\section{Podemann Sørensen, Jørgen}

1984 The Argument in Ancient Egyptian Magical Formulae. Acta Orientalia 45: 5-19.

\section{Sundén, Hjalmar}

1956 Sjuttiotredje psalmen och andra essäer. Stockholm: Diakonistyrelsen.

1959 Religionen och rollerna. Ett psykologiskt studium av fromheten. Stockholm: Diakonistyrelsen.

1987 Saint Augustine and the Psalter in the light of Role-Psychology. Journal for the Scientific study of Religion 26: 375-382.

\section{Turner, Victor}

1969 The Ritual Process. Structure and Anti-Structure. London: Routledge \& Kegan Paul.

1981 The Forest of Symbols. Aspects of the Ndembu Ritual. Ithaca: Cornell University Press.

1985a Liminality, Kabbalah, and the Media. Religion 15: 205-217.

1985b On the Edge of the Bush. Anthropology as Experience. Ed. by Edith L. B. Turner. Tucson: University of Arizona Press. 